\title{
A Review of Polycyclic Aromatic Hydrocarbons and Heavy Metal Contamination of Fish from Fish Farms
}

\author{
AJIBOYE, O O; YAKUBU, A F; ADAMS, T E \\ Nigerian Institute for Oceanography and Marine Research, Sapele, Delta State, Nigeria \\ P.M.B. 4015, Sapele, Delta State, Nigeria.
}

\begin{abstract}
Polycyclic aromatic hydrocarbons (PAHs) and heavy metals contribute to pollutants in aquaculture facilities and thus need to be further investigated. Besides, there is little information regarding PAHs and heavy metals in the tissues of cultured fish, and the risks associated to consumption. In this review, emphasis has been made on the detection of PAHs and heavy metals in cultured fish species which has relatively received little attention in the aquaculture industry compared to researches on the levels of PAHs and heavy metals from the wild catch. The review also focuses on the detection of PAHs and heavy metals in most of the feed ingredients commonly used in the formulation of feed for farmed fish species. The use of chemicals like antibiotics, feed additives, soil and water treatment and other products used in the aquaculture facility or site is also well emphasized and need to be well documented. Future research goals are well stressed and need to be given more attention in aquaculture. @JASEM
\end{abstract}

Key words: Polycyclic aromatic hydrocarbons; heavy metals; bioaccumulation; contamination.

The global consumption of fish and derived fish products has generally increased during recent decades (Wim et al., 2007) due to change from animal protein to fish protein with reduced cholesterol levels. It has been predicted that fish consumption in developing countries will increase by 57 percent, from 62.7 million metric tons in 1997 to 98.6 million in 2020 (Delgado et al., 2003). However, growing demand for aquatic products in both developing and developed countries has necessitated the need to maintain the present per capital supply of aquatic products in the future. Besides, practices such as environmental perturbations, overexploitation, dumping of agrochemicals and industrial pollutants, indiscriminate and destructive fishing practices in the aquatic systems not only reduces abundance and fish size but also poses health hazards to the consumers.

Massive amounts of domestic wastewater and industrial effluents are transported by rivers and discharged into the sea, contaminating rivers and coastal waters. Such anthropogenic pollutants are the main sources of heavy metal contaminants in the ocean (Lakshmanan et al., 2009). Heavy metals carried down by effluents are usually mentioned (see Table 1) and has been the major threats for fish consumers and the effects on the contamination of fishing products becomes now a serious issue to be addressed. The metal contaminants in aquatic systems usually remain either in soluble or suspension form and finally tend to settle down to the bottom or are taken up by the organisms (Reddy et al., 2007). Heavy metal contamination may have devastating effects on the ecological balance of the recipient environment and a diversity of aquatic organisms (Ashraj, 2005; Vosyliene and Jankaite, 2006).

Fishes being one of the main aquatic organisms in the food chain may often accumulate large amounts of certain metals (Mansour and Sidky, 2002). Among animal species, fishes are the inhabitants that cannot escape from the detrimental effects of these pollutants (Olaifa et al., 2004). Moreover, it is worthy to note that these heavy metals accumulate in various tissues and organs of fish species, which in turn may enter into the human metabolism through consumption causing serious health hazards. Hence, this review was undertaken as a perspective on the status and challenges of polycyclic aromatic hydrocarbons (PAHs) and heavy metals in fish species in fish farms, which has relatively received little attention in aquaculture.

Polycyclic Aromatic Hydrocarbons (Pahs) And Heavy Metals Contamination In Cultured Fish: Metal contamination in aquatic environments has received recently huge concern due to its toxicity, abundance and persistence in the marine environment, and subsequent accumulation in aquatic fauna and flora, which, in turn may enter into the human food chain and result in health problems (Heba, 2004). On the other hand, it must be well emphasized that the aquaculture industries are also exposed to many chemical, biological and other pollutants and polycyclic aromatic hydrocarbons (PAHs) also contributed to pollutants in aquaculture facilities and thus need to be further investigated.

Polycyclic aromatic hydrocarbons (PAHs) are wide spread organic pollutant in the environment; are well known for their mutagenic and carcinogenic effects and bioaccumulate in animal and human tissue. The sources of PAHs are both from natural and anthropogenic mainly from incomplete combustion of organic materials, fossil fuel and petroleum (Liang et $a l$, 2007). PAHs can also form in meat cooked or fish smoked at high temperatures. For example, it was reported by few authors (Storelli et al., 2003; Barranco et al., 2004; Purcaro et al., 2006) that PAHs are found in substantial quantities in some foods, 
depending on the mode of cooking, preservation and storage. However, more research is needed in this area and need to be further investigated. Besides, there is little information regarding PAHs and heavy metals in the tissues of cultured fish, and the risks associated to consumption.

The only study conducted in cultured fish in Linggi estuary, Malaysia (Shahrizat, 2005) recorded high concentration of $\mathrm{Pb}$ and $\mathrm{Cd}$ in the tissue of cultured fish. In China, fish from aquaculture cages in coastal waters were analyzed for PAHs. Naphthalene and phenanthrene were detected in fish bile (Klumpp et al., 2002). This is the scenario of PAHs detected in fishes from wild catch and also aquaculture. The concentrations of these elements are above than the permissible level set by the Malaysian Government. Concordantly, a study was designed to assess levels of exposure to metals, organochlorinated compounds, PAHs and alkylphenols (APEs) in farmed sea bass (Dicentrarchs labrax) from five aquacultures located in Southern Europe (Fernandes et al., 2008). The research findings showed that pollutants exposure in farmed fish is similar to the levels reported in wild specimens from the area. On the other hand, it is worth noting that the absorption of metals in different fish species is to a large extent a function of their respective membrane permeability and enzyme system, which is highly species specifics and because of this fact different metals accumulated in different orders in different fish samples (Table 2). However, future research work should focus more attention on PAHs and heavy metals most especially in the tissues of farmed fish, and the risks associated to consumption. According to Llobet et al (2006), the main reason for concern following human exposure to these compounds is that several PAHs are carcinogenic. Various recent epidemiological studies have revealed that dietary exposure to PAHs is associated with an increased risk of some human cancers (Anderson et al., 2005; Purcaro et al., 2006).

Furthermore, it must be well emphasized that formulated feed is one of the main sources of PAHs in the aquaculture industries. For example, a recent investigation carried out (Wang et al., 2010) on the enrichment and sources of PAHs in mariculture sediments collected from six farms in Hong Kong and reference sites showed that moderately high $\Sigma \mathrm{PAH}_{16}$ levels (123-947 $\mathrm{ng} \mathrm{g}^{-1}$, mean: $450 \mathrm{ng} \mathrm{g}^{-1}$ ) were found in the surface aquaculture sediments while the average enrichment percentage of total organic carbon (TOC) and PAHs in surface sediments were 21.4 and $43.8 \%$, respectively, and in the core sediments, 24.6 and $73.7 \%$, respectively. According to those authors (Wang et al., 2010), the fish feeds might be the main source of the enriched PAHs in the aquaculture sediments. A recent survey conducted (Falcó et al., 2005) in which the concentrations of various chemical contaminants were determined in 11 groups of foodstuffs acquired in Catalonia (Spain) showed that the highest total concentrations of PAHs were found in cereals, meats, oils and fats, and fish and other sea food. Besides, researchers need to be aware of the fact that most of these foodstuffs (e.g. cereals), oils and fats and even fish or large amount of fishery by-products and by-catch that are produced annually as fish silage and shrimp meals are being used as feed ingredients in the formulation of feed in the aquaculture industry. From a toxicological point of view, future research efforts should focus on the concentration of PAHs in most of the feed ingredients commonly used in the formulation of feed for farmed fish. In addition, most of the chemicals like feed additives that are being used in the aquaculture industry need to be thoroughly investigated from a toxicological point of view.

Table 1. Heavy metals contents in water, sediment and fish from different lakes

\begin{tabular}{|c|c|c|c|c|c|c|c|}
\hline Locations & Mediums & $\mathrm{Cd}$ & $\mathrm{Cu}$ & $\mathrm{Hg}$ & $\mathrm{Pb}$ & $\mathrm{Zn}$ & Reference \\
\hline Odo-Iyaalaro (tributary of Lagos & Water $\mathrm{mgl}^{-1}$ & 1.9 & 22 & - & 25 & 64.5 & Oyeyiola et al (2006) \\
\hline Lagoon, Nigeria) & Sediments $\mathrm{mgl}^{-1}$ & 42.1 & 94.5 & - & 108.3 & 805 & \\
\hline Urban lakes in Yaoudé, Cameroon & Water $\mu \mathrm{gl}^{-1}$ & - & - & - & 20.1 & 90.2 & Demanou, J; Brummett RE (2003) \\
\hline \multirow[t]{2}{*}{ Lake Victoria, Tanzania } & Sediment $\mathrm{mgg}^{-1}$ & $<1.9$ & 32.6 & \multirow[t]{2}{*}{ - } & 58.1 & 101.9 & \multirow[t]{2}{*}{ Machiwa, JF (2003) } \\
\hline & Fish mgg $^{-1}$ & 4.67 & 07 & & 0.13 & 8.8 & \\
\hline Fouarat lake, Morocco & Sediment $\mu \mathrm{gg}^{-1}$ & 0.9 & 75 & - & 110 & 400 & Bouih, BH. et al (2005) \\
\hline Lakes Awassa, Ziway, Ethiopia & Fish $\mathrm{mgkg}^{-1}$ & 4.9 & 797 & - & 42.3 & 115.9 & Aweke, K. Taddese, W (2004) \\
\hline Santa Gilla lagoon, Italy & Sediment ppm & - & 33 & 6.28 & 172 & 209 & Deguetto, S. et al (1997) \\
\hline Marano lagoon, Italy & Sediment $\mu \mathrm{gg}^{-1}$ & - & - & 6.6 & - & - & Piani, R. et al (2005) \\
\hline Lake Killamey Park, Canada & Sediment $\mathrm{mgkg}^{-1}$ & 12 & 189 & - & 253 & 1132 & Belzile, N. et al (2004) \\
\hline
\end{tabular}

Table 2. Trace metal concentrations and related statistical parameter for various samples of fish \# Mean \pm SD

\begin{tabular}{|l|l|l|l|l|l|l|}
\hline S/No & Metals & $\begin{array}{l}\text { Upeneus } \\
\text { vittatus }\end{array}$ & $\begin{array}{l}\text { Anchovilla } \\
\text { commersonii }\end{array}$ & $\begin{array}{l}\text { Pomadasys } \\
\text { maculates }\end{array}$ & $\begin{array}{l}\text { Lutjanus } \\
\text { adetii }\end{array}$ & $\begin{array}{l}\text { Ambassis } \\
\text { commersoni }\end{array}$ \\
\hline 1 & $\mathrm{Cd}$ & $0.008 \pm 0.00$ & $0.114 \pm 0.14$ & $0.006 \pm 0.00$ & $0.004 \pm 0.00$ & $0.012 \pm 0.01$ \\
\hline 2 & $\mathrm{Co}$ & $0.009 \pm 0.00$ & $0.014 \pm 0.00$ & $0.008 \pm 0.00$ & $0.008 \pm 0.00$ & $0.006 \pm 0.00$ \\
\hline 3 & $\mathrm{Cr}$ & $0.415 \pm 0.27$ & $1.168 \pm 1.49$ & $1.562 \pm 1.56$ & $0.467 \pm 0.14$ & $1.146 \pm 1.25$ \\
\hline 4 & $\mathrm{Zn}$ & $0.807 \pm 0.13$ & $0.103 \pm 0.14$ & $0.282 \pm 0.12$ & $0.225 \pm 0.14$ & $0.245 \pm 0.16$ \\
\hline 5 & $\mathrm{~Pb}$ & $0.062 \pm 0.00$ & $1.569 \pm 1.41$ & $1.066 \pm 1.49$ & $0.861 \pm 0.14$ & $1.264 \pm 1.48$ \\
\hline
\end{tabular}

(C) Lakshmanan et al (2009) 
Future Research Goals: If we seriously aim at culturing and harvesting fish products that is safe for human consumption, conscious research efforts must focus on the following real and achievable research goals for future:

The levels of polycyclic aromatic hydrocarbons (PAHs) and heavy metals in cultured fish species need to be evaluated. In fact, most of the researches conducted focus more attention on the detection of PAHs and heavy metals from the wild catch (Pointet, 2000; Llobet et al., 2006; Liang et al, 2007; Lakshmanan et al., 2009) while relatively little attention is focused on the levels of PAHs and heavy metals in cultured fish species. In addition, PAHs and heavy metals concentrations in water, sediments and most importantly in the tissues and blood of farmed fish species from aquaculture fish ponds need to be thoroughly evaluated.

The quality of the fish (both wild catch and aquaculture) for human consumption and the health risks associated with the aquatic products need to be given more priority. The mutagenic and carcinogenic effects of PAHs on commercially important sea food products need to be thoroughly investigated. If possible, epidemiological studies on the dietary exposure to PAHs need to be conducted.

The chemicals like antibiotics, feed additives, soil and water treatment and other products used in the aquaculture facility or site need to be well documented.

From a toxicological point of view, most of the human aquaculture activities such as the use of chemicals like feed additives, antibiotics, soil and water treatment, etc need to be stressed and thoroughly investigated. Detection of heavy metals and PAHs in most of the feed ingredients commonly used in the formulation of feed for cultured fish species need to be evaluated.

Conclusion: The studies carried out on various fishes have shown that heavy metals may alter the physiological activities and biochemical parameters both in tissues and in blood. It is also evident from this review that the study of the presence of polycyclic aromatic hydrocarbons (PAHs) and heavy metals in the aquaculture environment is of global importance because they play an important role in the cultured fish bioaccumulation of transfer of heavy metals especially when they passed on to human being through the consumption of fish and other aquatic products. However, more research is needed in this area.

Interestingly, the accumulation of heavy metals in various tissues in most popular and commercially important fish species has been quantitatively studied. On the other hand, it is worthy to note that little attention is focused on the reduction of anthropogenic pollutants such as industrial effluents, domestic sewage and mining wastes which are the main sources of heavy metal contaminants in the ocean. Concordantly, most of the human aquaculture activities such as the use of chemicals like feed additives, antibiotics, soil and water treatment need to be addressed and thoroughly investigated from a toxicological point of view.

Most importantly, each Government agencies should ensure that the standard set to ensure that the concentrations of these elements are not above than the permissible level set is strictly adhered to.

\section{REFERENCES}

Anderson, KE., Kadlubar, FF., Kulldorff, M., Harnack, L., Gross, M., Lang, NP., Barber, C., Rothman, N., Sinha, R (2005) Dietary intake of heterocyclic amines and benzo(a)pyrene: associations with pancreatic cancer. Cancer Epidemiol. Biomarkers Prev., 14: 2261-2265.

Ashraj, W (2005) Accumulation of heavy metals in kidney and heart tissues of Epinephelus microdon fish from the Arabian Gulf. Environ. Monit. Assess., 101 (1-3): 311-316.

Aweke, K., Taddese, W (2004) Distribution of trace elements in muscle and organs of tilapia, oreochromis niloticus, from lakes Awassa and Ziwa, Ethiopia. Bull. Chem. Soc. Ethiop., 18(2): 119-130.

Barranco, ARM., Alonso-Salces, I., Crespo, LA., Berrueta, B., Gallo, FV., Sarobe, M (2004) Polycyclic aromatic hydrocarbon content in commercial Spanish fatty foods. J. Food Prot., 67: 2786-2791.

Belzile, N., Chen, Y-W., Gunn, JM., Dixit, SS (2004) Sediment trace metal profiles in lakes of Killarney Park, Canada: from regional to continental influence. Environmental Pollution, 130: 239-248.

Bouih, BH., Nassali, H., Leblans, M., Srhiri, A (2005) Contamination en métaux traces des sédiments du lac Fouarat (Maroc). Afrique Science, 1(1): 109-125.

Deguetto, S., Schintu, M., Contu, A., Sbrignadello, G (1997) Santa Gilla lagoon (Italy): a mercury sediment pollution case study. Contamination assessment and restoration of the site. The Science of the Total Environment, 204: 49-56.

Delgado, CL., Wasa, N., Rosegrant, MW., Meijer, S., Muhfuzuddin, A (2003) Fish to 2020. Supply and Demand in Changing Global Markets. Washington, DC: International Food Policy Research Institute/World Fish Centre. 
Demanou, J., Brummett, RE (2003) Heavy metal and faecal bacterial contamination of urban lakes in Yaoundé, Cameroon. Afr. J. Aqua. Sci., 28(1): 4956.

Falcó, G., Bocio, A., Llobet, JM., Domingo, JL (2005) Health risks of dietary intake of environmental pollutants by elite sportsmen and sportswomen. Food Chem. Toxicol., 43: 17131721.

Fernandes, D., Zanuy, S., Bebianno, MJ., Porte, C (2008) Chemical and biochemical tools to assess pollution exposure in cultured fish. Environ. Pollut., 152(1): 138-146.

Heba, HM (2004) Distribution of trace elements in the white muscles and some key organs of fish species from Al-Hodiedah Red Sea Coast of Yemen. Proc. I.C. BS, 3(1): 435 - 454.

Klumpp, D., Huasheng, H., Humphrey, C., Xinhong, W., Codi, S (2002) Toxic contaminants and their biological effects in coastal waters of Xiamen, China. I. Organic pollutants in mussel and fish tissues. Marine pollution bulletin, 44(8), 752-760.

Lakshmanan, R., Kesavan, K., Vijayanand, P., Rajaram, V., Rajagopal, S (2009) Heavy metals accumulation in five commercially important fishes of Parangipettai, Southeast Coast of India. Advance Journal of Food Science and Technology, 1 (1): 63-65.

Liang, Y., Tse, MF., Young, L., Wong, MH (2007) Distribution pattern of polycyclic aromatic hydrocarbons (PAHs) in the sediments and fish at Mai Po Marshes Nature Reserve, Hong Kong. Water Research, 41: 1301-1311.

Llobet, JM., Falcó, G., Bocio, A., Domingo, JL (2006) Exposure to polycyclic aromatic hydrocarbons through consumption of edible marine species in Catalonia, Spain. Journal of Food Protection, 69(10): 2493-2499.

Machiwa, JF (2003) Metal concentrations in sediment and fish of lake Victoria near and away from catchments with gold mining activities. Tanz. J. Sci., 29(2): 43-54.

Mansour, SA., Sidky, MM (2002) Heavy metals contaminating water and fish from Fayoum Governorate, Egypt. Food Chem., 78: 15-22.

Olaifa, FG., Olaifa, AK., Onwude, TE (2004) Lethal and sublethal effects of copper to the African cat fish (Clarias gariepnus). Afr. J. Biomed. Res., 7: 65-70.
Oyeyiola, AO., Olayinka, KO., Alo, BI (2006) Correlation studies of heavy metals concentration with sediment properties of some rivers surrounding the Lagos lagoon. Nigerian Journal of Health and Biomedical Sciences, 5(1): 118-122.

Piani, R., Covelli, S., Biester, H (2005) Mercury contamination in Marono lagoon (Northen Adriatic sea, Italy): Source identification by analyses of $\mathrm{Hg}$ phases. Applied Geochemistry, 20: 1546-1559.

Pointet, KAM (2000) PAHs analysis of fish whole gall bladders and livers from the Natural Reserve of Camargue by GCMS. Chemosphere, 40: 293399.

Purcaro, G., Navas, JA., Guardiola, F., Conte, LS., Moret, S (2006) Polycyclic aromatic hydrocarbons in frying oils and snacks. J. Food Prot., 69: 199-204.

Redddy, MS., Mehta, B., Dave, S., Joshi, M., Karthikeyan, L., Sarma, VKS., Basha, S., Ramachandraiah, G., Bhatt, P (2007) Bioaccumulation of heavy metals in some commercial fishes and crabs of the Gulf of Cambay, India. Current Science, Vol. 92, No. 11. pp. 1489-1491.

Shahrizat, Y (2005) Distribution and Accumulation of Heavy Metals in Fish Cage System in Linggi Estuary, Malaysia. Master Thesis. Faculty of Science, Universiti Putra Malaysia.

Storelli, MM., Stuffler, RG., Marcotrigiano, GO (2003) Polycyclic aromatic hydrocarbons, polychlorinated biphenyls, chlorinated pesticides (DDTs), hexachlorocyclohexane, and hexachlorobenzene residues in smoked seafood. J. Food Prot., 66: 1095-1099.

Vosyliene, MZ., Jankaite, A (2006) Effect of heavy metal model mixture on rainbow trout biological parameters. Ekologija., 4: 12-17.

Wang, HS., Liang, P., Kang, Y., Shao, DD., Zheng, GJ., Wu, SC., Wong, CK., Wong, MH (2010) Enrichment of polycyclic aromatic hydrocarbons in mariculture sediments of Hong Kong. Environmental Pollution, 158 (10): 3298-3308.

Wim, V., Issabelle, SK., Stefan, DH., John, VC (2007) Consumer perception versus scientific evidence of farmed and wild fish: exploratory insights for Belgium. Aquaculture International, 15: $121-136$. 